\title{
山形県における虚血性脳卒中症例の再発および 全死亡に関係する危険因子の検討
}

\author{
山形県対脳卒中治療研究会*
}

\begin{abstract}
要旨：【背景および目的】生活習慣病と虚血性脳卒中の再発および死亡との関係は長期観察が困難 な点から十分に検討されていない．山形県の脳卒中登録事業から得た脳卒中データベースから，虚 血性脳卒中の再発および全死亡と諸因子との関係を検討した。【方法】虚血性脳卒中を発症した 544 症例に対し, 発症から 2 年間追跡調查を行った.【結果】観察期間に抢いて, 25 例の虚血性脳卒中再 発拧よび 34 例の死亡を確認した．多変量解析では，再発例で糖尿病，高血圧，高コレステロール血 症の存在 (HR 2.72) および脳卒中の既往 (HR 3.69) が独立した危険因子であった．死亡には年齢，糖尿 病と高血圧の存在, 抗血栓療法, 虚血性脳卒中の病型, modified Rankin Scale が関係していた.【結 論]糖尿病に高血圧等が合併することは, 虚血性脳卒中の再発および死亡に関係し, 代謝性危険因子 の管理が二次予防において重要である.
\end{abstract}

Key words: ischemic stroke, stroke recurrence, all-cause mortality, risk factors, secondary prevention

\section{はじめに}

脳梗塞の一次予防は最も重要な医療政策であるが, 脳 梗塞の再発は, 介護を必要とする患者の増加, あるいは 血管性認知症の発症とも関係しており, 脳梗塞の二次予 防も重要課題の一つといえる。 この 30 年間に, 高血圧 治療, 抗血栓療法などが脳卒中の相対危険率の低下に寄 与したと考えられるが1), 脳梗塞の再発あるいは脳梗塞 患者の死亡にどのような要因が関係しているのかは完全 には明らかにされていない. 脳梗塞の発症と生活習慣病 との関係を一次予防の観点から検討した疫学研究は多数 存在する ${ }^{2,3)}$ が, その一方で, 脳梗塞再発についての前向 き研究は少なく, 脳梗塞患者の長期にわたる追跡調查が 困難であることがその理由に挙げられる，現在までに， 一般住民を対象とした疫学研究において, 糖尿病および 高血圧は脳梗塞発症後の死亡の独立した危険因子とさ れ ${ }^{4,5)}$, また, 本邦において糖尿病は脳梗塞再発の危険因 子とされる(6)など, 生活習慣病が脳梗塞の再発および死 亡に強く関係していると考えられる.

今回我々は，山形県における多施設共同脳卒中デー夕

山形大学医学部内科学第三講座

(2014 年 4 月 9 日受付, 2014 年 4 月 25 日受理)
ベースを用い, 虚血性脳卒中発症後の虚血性脳卒中の再 発, 死亡ならびに背景因子との関係について検討した.

\section{対象および方法}

山形県対脳卒中治療研究会*は, 山形大学医学部およ び山形県内の関連病院(山形市立病院済生館, 山形県立 中央病院，鶴岡市立荘内病院，日本海総合病院，米沢市 立病院, 公立置賜総合病院, 県立河北病院, 県立新庄病 院, 北村山公立病院, 山形済生病院, 国立病院機構山形 病院, 国立病院機構米沢病院) から構成され, 県内の脳 外科医および神経内科医により脳卒中患者を登録しデー タベースを作成している.

対象は上述の医療機関に入院した発症 7 日以内の虚血 性脳卒中患者で, 2007 年 1 月 1 日から 2008 年 12 月 31 日までに患者本人あるいは家族から同意の得られた 544 例を対象とした．同意を取得した後に，急性期臨床情報 および退院後の再発, 死亡についての追跡調査を行っ た. 退院後の再発および死亡についての臨床情報は, 虚 血性脳卒中発症から 6,12 および 24 力月後に担当医が 診療あるいは電話などのインタビューを行い確認した。 虚血性脳卒中の病型は National Institute for Neurological Disorders and Stroke の臨床病型7)により，1）ラクナ梗塞, 2)アテローム血栓性脳梗塞, 3) 心原性脳塞栓, 4) その他 


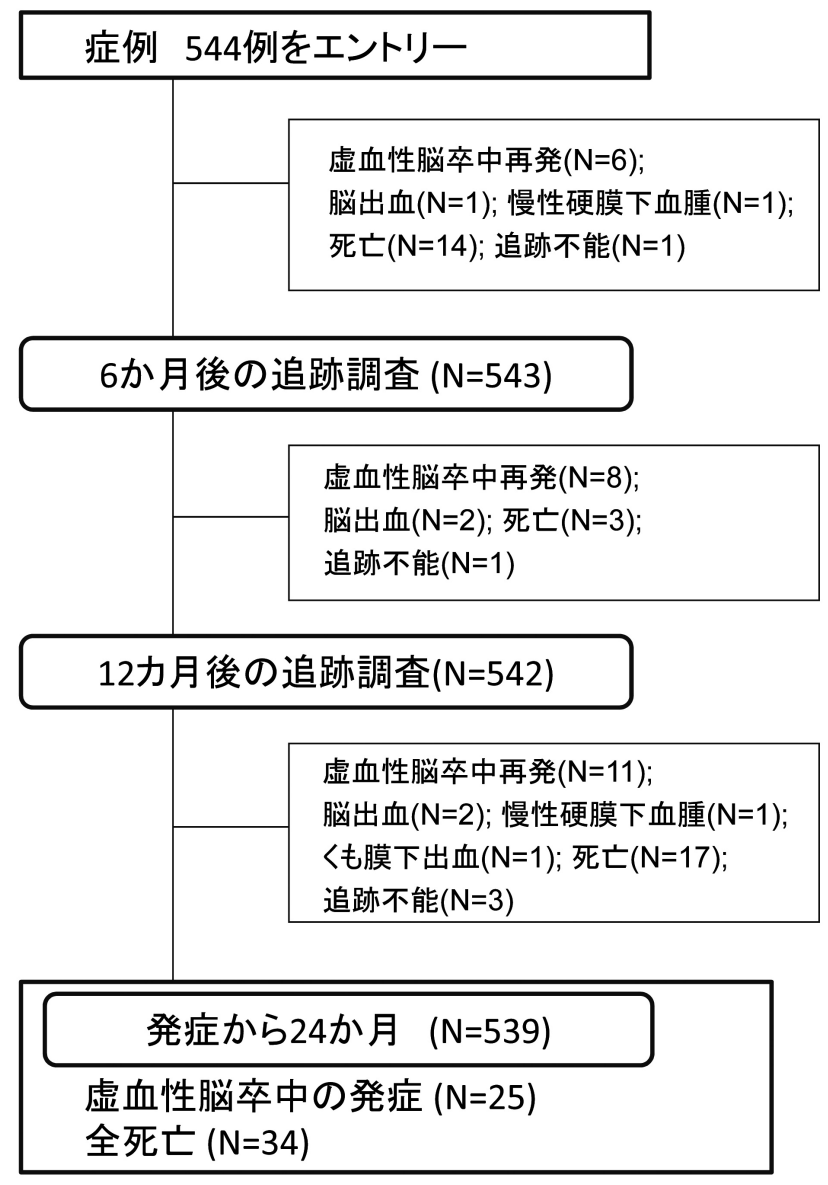

Fig. 1 虚血性脳卒中症例の追跡調査の流れ

に分類した．また，生活習慣病については，(1)高血圧症 は, 高血圧症の既往のあるもの, (2)糖尿病は, 糖尿病の 既往, あるいは入院時血糖が $200 \mathrm{mg} / \mathrm{dl}$ 以上もしくはへ モグロビン A1c (NGSP 值) 6.5\%以上，(3)高コレステロー ル血症は, 高脂血症の既往のあるもの, あるいは入院時 総コレステロールが $220 \mathrm{mg} / \mathrm{dl}$ 以上のものと定義した. 脳卒中の既往は, 今回の虚血性脳卒中発症以前に脳卒中 を発症したものと定義した。また，一部の症例 $(\mathrm{n}=360)$ は退院時の modified Rankin Scale (mRS) とその後の再発 および死亡との関係について検討した. エンドポイント は虚血性脳卒中の発症および全死亡とし，これらの発症 を解析に用いた。

統計解析は, 2 群間の比較には, 連続変数では t-test を, また離散変数では $\chi^{2}$ 検定を用い解析した. エンド ポイント(再発および全死亡) と諸因子との関係について 単変量解析を行い, 単変量解析の結果から, 統計学的に 有意差を認めた臨床パラメータを用い，コックス比例ハ ザードモデルを用い多変量解析を行った。また，再発お よび生存率の検討には Kaplan-Meier 法を用い，有意差の 検定には Log rank test を用いた。
Table 1 虚血性脳卒中発症時の臨床パラメーター

\begin{tabular}{ll}
\hline & $\mathrm{N}=544$ \\
\hline 年齢, (平均士標準偏差) & $68.4 \pm 11.5$ \\
男性, \% & 65.3 \\
高血圧症, \% & 69.9 \\
糖尿病, \% & 25.0 \\
高コレステロール血症, \% & 36.4 \\
喫煙, \% & 23.7 \\
虚血性脳卒中の臨床病型 & \\
ラクナ梗塞, \% & 30.7 \\
アテローム血栓性脳梗塞, \% & 42.1 \\
心原性脳塞栓, \% & 20.8 \\
その他 (TIA を含む), \% & 6.4 \\
抗血栓療法, \% & 92.4 \\
脳卒中の既往, \% & 16.2 \\
\hline
\end{tabular}

統計解析はSPSS 15.0(SPSS Inc.)を用い，それぞれ $p<0.05$ を統計学的に有意差有りとした.

\section{結果}

登録した虚血性脳卒中 544 例の平均観察期間は 22.4 カ月であり， 2 年間で虚血性脳卒中を 25 例に認め, 34 例の死亡を確認した(Fig. 1)。登録患者背景を Table 1 に 示す。平均年齢は $68.4 \pm 11.5$ 歳, 男性が $65.3 \%$ であっ た．臨床分類はアテローム血栓性脳梗塞が $42.1 \%$ と最も 多く，生活習慣病では高血圧症が $69.9 \%$, 糖尿病が $25.0 \%$ であり，全体の $92.4 \%$ が虚血性脳卒中の発症後に 抗血栓療法を継続した.

虚血性脳卒中再発群と非再発群の臨床パラメー夕を Table 2 に示す.

再発および非再発群の 2 群間では生活習慣病の頻度 （高血圧症と糖尿病を有すること，糖尿病，高血圧に加 え高コレステロール血症を有すること)，加えて脳卒中 の既往が再発群で多く，統計学的有意差を認めた。 ま た, 単変量解析 (Cox hazard regression model) でもこれら の臨床パラメータに統計学的有意差が認められた。

死亡群および非死亡群における背景因子を検討すると 年齢, 生活習慣病(糖尿病と高血圧症)，心房細動，抗血 栓療法, 非心原性脳塞栓症における抗血小板療法, 心原 性脳塞栓症における抗凝固療法, 虚血性脳卒中の臨床病 型および $\mathrm{mRS}(\mathrm{n}=360)$ において単変量分析で統計学的有 意差が認められた (Table 3)。単変量解析で統計学的有意 差を認めた臨床パラメー夕を用い多変量解析を行ったと ころ, 糖尿病, 高血圧および高コレステロール血症の 3 つの生活習慣病を有することが虚血性脳卒中再発の独立 
Table 2 単変量解析等による虚血性脳卒中再発と臨床パラメーターとの関係

\begin{tabular}{|c|c|c|c|c|}
\hline & $\begin{array}{c}\text { 再発あり } \\
(\mathrm{n}=25)\end{array}$ & $\begin{array}{c}\text { 再発なし } \\
(\mathrm{n}=519)\end{array}$ & $\begin{array}{c}\text { ハザード比 } \\
(95 \% \text { CI })\end{array}$ & $\mathrm{P}$ 值 \\
\hline \multicolumn{5}{|l|}{ 脳卒中発症時の臨床パラメーター } \\
\hline 年齢, 歳 & $67.8 \pm 10.2$ & $68.5 \pm 11.6$ & $0.99(0.96-1.03)$ & 0.826 \\
\hline 男性，\% & 68.0 & 65.1 & $0.89(0.39-2.07)$ & 0.788 \\
\hline 高血圧症，\% & 72.0 & 69.7 & $1.13(0.47-2.71)$ & 0.780 \\
\hline 高コレステロール血症, \% & 48.0 & 35.8 & $1.64(0.75-3.59)$ & 0.218 \\
\hline 糖尿病，\% & 40.0 & 24.3 & $2.08(0.94-4.63)$ & 0.073 \\
\hline $\mathrm{DM}+\mathrm{HT}, \quad \%$ & $36.0^{*}$ & 19.1 & $2.42(1.07-5.48)$ & 0.034 \\
\hline $\mathrm{DM}+\mathrm{HT}+\mathrm{HC}, \%$ & $24.0^{*}$ & 10.2 & $2.90(1.16-7.27)$ & 0.023 \\
\hline 喫煙，\% & 20.0 & 23.9 & $0.80(0.30-2.14)$ & 0.658 \\
\hline 心房細動，％ & 12.0 & 17.0 & $0.72(0.22-2.40)$ & 0.589 \\
\hline 抗血栓療法, \% & 88.0 & 92.6 & $0.54(0.16-1.82)$ & 0.323 \\
\hline \multicolumn{5}{|l|}{ 脳卒中の既往・病型 } \\
\hline 脳卒中の既往歴，\% & $40.0^{*}$ & 15.1 & $3.82(1.72-8.51)$ & 0.001 \\
\hline \multicolumn{5}{|l|}{ 虚血性脳卒中の臨床病型 } \\
\hline ラクナ梗塞，\% & 28.0 & 30.8 & $0.83(0.35-1.99)$ & 0.677 \\
\hline アテローム血栓性脳梗塞, \% & 40.0 & 42.2 & $0.92(0.41-2.05)$ & 0.838 \\
\hline 心原性脳塞栓症，\% & 24.0 & 20.6 & $1.28(0.51-3.20)$ & 0.603 \\
\hline その他 $(\mathrm{TIA}$ を含む), \% & 8.0 & 6.3 & & \\
\hline Modified Rankin Scale ( $n=360$ ), 中央值 & 1 & 1 & $0.89(0.62-1.27)$ & 0.507 \\
\hline
\end{tabular}

*; $p<0.05$

$\mathrm{DM}$; 糖尿病, $\mathrm{HT}$; 高血圧症, $\mathrm{HC}$; 高コレステロール血症

Table 3 単変量解析等による全死亡と臨床パラメーターとの関係

\begin{tabular}{|c|c|c|c|c|}
\hline & $\begin{array}{c}\text { 死亡あり } \\
(\mathrm{n}=34)\end{array}$ & $\begin{array}{c}\text { 死亡なし } \\
(\mathrm{n}=510)\end{array}$ & $\begin{array}{c}\text { ハザード比 } \\
(95 \% \text { CI })\end{array}$ & $\mathrm{P}$ 值 \\
\hline \multicolumn{5}{|l|}{ 脳卒中発症時の臨床パラメーター } \\
\hline 年齢, 歳 & $75.8 \pm 7.9 * *$ & $68.0 \pm 11.5$ & $1.07(1.03-1.11)$ & $<0.001$ \\
\hline 男性，\% & 70.6 & 64.9 & $0.79(0.38-1.65)$ & 0.531 \\
\hline 高血圧症，\% & 79.4 & 69.2 & $1.69(0.74-3.88)$ & 0.215 \\
\hline 高コレステロール血症，\% & 23.5 & 37.3 & $0.55(0.25-1.21)$ & 0.135 \\
\hline 糖尿病，\% & 38.2 & 24.1 & $1.93(0.97-3.86)$ & 0.062 \\
\hline $\mathrm{DM}+\mathrm{HT}, \quad \%$ & $38.2 * *$ & 18.6 & $2.67(1.33-5.32)$ & 0.005 \\
\hline $\mathrm{DM}+\mathrm{HT}+\mathrm{HC}, \quad \%$ & 20.6 & 10.2 & $2.39(1.03-5.48)$ & 0.040 \\
\hline 喫煙，\% & $38.2^{*}$ & 22.7 & $1.97(0.99-3.94)$ & 0.054 \\
\hline 心房細動，％ & $32.4^{*}$ & 15.7 & $2.50(1.23-5.17)$ & 0.012 \\
\hline 抗血栓療法, \% & $71.9^{* *}$ & 93.7 & $0.19(0.09-0.42)$ & $<0.001$ \\
\hline 非心原性脳塞栓における抗血小板療法，\% & $68.8^{*}$ & 88.3 & $0.29(0.10-0.84)$ & 0.022 \\
\hline 心原性脳塞栓における抗凝固療法，\% & $50.0^{* *}$ & 89.6 & $0.16(0.06-0.43)$ & $<0.001$ \\
\hline \multicolumn{5}{|l|}{ 脳卒中の既往・病型 } \\
\hline 脳卒中の既往歴，\% & 23.5 & 15.7 & $1.76(0.80-3.90)$ & 0.161 \\
\hline \multicolumn{5}{|l|}{ 脳梗塞の臨床病型** } \\
\hline ラクナ梗塞, \% & 5.9 & 32.4 & $0.13(0.03-0.56)$ & 0.006 \\
\hline アテローム血栓性脳梗塞, \% & 38.2 & 42.4 & $0.85(0.43-1.70)$ & 0.645 \\
\hline 心原性脳塞栓症，\% & 50.0 & 18.8 & $4.08(2.08-7.99)$ & $<0.001$ \\
\hline その他(TIA を含む), \% & 5.9 & 6.5 & & \\
\hline Modified Rankin Scale $(n=360)$, 中央值 & $4.5^{* *}$ & 1 & $2.78(2.00-3.87)$ & $<0.001$ \\
\hline
\end{tabular}

${ }^{*} ; p<0.05, \quad{ }^{* *} ; p<0.01$

$\mathrm{DM}$; 糖㽷病, $\mathrm{HT}$; 高血圧症, $\mathrm{HC}$; 高コレステロール血症 
Table 4 多変量解析による諸因子と全死亡との関係

\begin{tabular}{llc}
\hline & \multicolumn{2}{c}{ ハザード比 $(95 \% \mathrm{CI})$} \\
\cline { 2 - 3 } & \multicolumn{1}{c}{ Model 1 } & Model 2 \\
\hline 年齢 / 年 & $1.07(1.03-1.11)^{* *}$ & $1.05(1.01-1.09)^{* *}$ \\
糖尿病 + 高血圧症 & $2.92(1.46-5.85)^{* *}$ & $2.99(1.42-6.32)^{* *}$ \\
抗血栓療法 & $0.23(0.10-0.49)^{* *}$ & $0.18(0.08-0.41)^{* *}$ \\
心房細動 & $2.51(1.23-5.16)^{*}$ & $1.12(0.47-2.66)$ \\
ラクナ梗塞 & $0.14(0.03-0.59)^{* *}$ & $0.14(0.03-0.64)^{*}$ \\
心原性脳塞栓症 & $3.79(1.89-7.58)^{* *}$ & $2.45(1.17-5.11)^{*}$ \\
Modified Rankin Scale $(\mathrm{n}=360)$ & $2.78(2.00-3.87)^{* *}$ & $2.75(1.97-3.85)^{* *}$ \\
\hline
\end{tabular}

$* ; p<0.05, \quad * * ; p<0.01$

Model 1：年齢および性で補正

Model 2: 年齢, 性, および単変量解析で有意差を認めた従属変数で補正

した危険因子となり(ハザード比 2.72)，また，脳卒中の 既往も再発の独立した危険因子であった。同様に，虚血 性脳卒中患者の死亡に関係した危険因子としては年齢 (ハザード比 1.05)，高血圧症と糖尿病を有すること(ハ ザード比 2.99) および $\mathrm{mRS}(\mathrm{n}=360)$ が死亡の独立した危 険因子であった (Table 4)。また，抗血栓療法および臨床 病型も全死亡に関係していた。

また，糖尿病等の3つの生活習慣病を有するグループ は，これらの生活習慣病のないグループと比較し，虚血 性脳卒中の再発率は高かった (Log rank test, $p=0.008)$.

Kaplan-Meier 生存曲線では糖尿病と高血圧の存在は虚血 性脳卒中発症後の全死亡に関係し，統計学的有意差を認 めた $(p=0.004)$ 。また， mRS を 3 群間に分け (Grade $0 〜 1$, 2〜3，4〜5) 全死亡との関係を検討したところ， mRS に よる重症度とその後の死亡は関係していた $(p<0.001)$.

\section{考察}

今回の研究結果から, 糖尿病を含む複数の生活習慣病 の存在は, 虚血性脳卒中の再発およびその後の死亡に関 係し，独立した危険因子であった，対象患者の大多数は 抗血栓療法が行われており, 二次予防においても, 生活 習慣病が複合的に虚血性脳卒中の再発に関与することが 示唆された。

高血圧症抢よび糖尿病は脳梗塞の独立した危険因子と され2,3)，生活習慣病対策は脳梗塞の発症を抑制する上で 重要である。わが国では，1970年代より降圧剤が普及 するとともに脳卒中死亡率が減少した ${ }^{8}{ }^{8}$ ， 国民生活レ ベルの向上とともに糖尿病が増加し, 脳梗塞に与える影 響も増大した．糖尿病をコントロールすることは脳梗塞 の発症を抑えるうえで重要と考えられるが，糖尿病患者 を対象とし，脳卒中の一次予防を検討したUnited
Kingdom Prospective Diabetes Study では血糖のコントロー ルのみでは脳卒中予防効果はなく，厳格な降圧療法によ り脳卒中予防効果が認められ9 ，包括的なリスク管理が 脳梗塞発症を抑制することが示された。また，糖尿病患 者におけるインスリン抵抗性は, 虚血性脳卒中に関係す ることが報告されてきたが ${ }^{10)}$ ，近年報告された糖尿病へ の治療介入研究 (PROspective pioglitAzone Clinical Trial In macro Vascular Events; PROactive) は，インスリン抵抗性 を改善させることで脳血管イベントを減少させ ${ }^{111}$ ，その 結果として二次予防に寄与することが示唆された，一次 予防を含めた糖尿病患者の脳梗塞発症抑制には，血糖值 のみならず，血圧や脂質といった他の危険因子を含めた 包括的な管理が必要であると考えられる.

この 30 年間に, 脳卒中の相対危険率は著しく低下し たが ${ }^{1)}$ ，虚血性脳卒中の再発あるいはその後の死亡にど のような要因が関係しているのかは完全には明らかにさ れていない.一次予防と比較し，二次予防に焦点をあて た疫学研究は少なく，また，虚血性脳卒中の二次予防に ついての降圧目標あるいは血糖值など，エビデンスを 持った治療指針も十分に明らかにされていない，その背 景には，(1)脳梗塞患者のその後の追跡調査が難しいこ と, (2)脳梗塞の再発には生活習慣病以外にも, 収入や介 護など複数の要因が複雑に関与している可能性が考えら れる。

本研究の結果から, 糖尿病, 高血圧症揖よび高コレス テロール血症を有することは虚血性脳卒中再発の独立し た危険因子と考えられるが，過去の疫学研究でも，複数 の生活習慣病が複合的リスクとして虚血性脳卒中再発と 関係することが報告されている ${ }^{12)}$.

糖尿病，高血圧症および脂質異常症といった生活習慣 病は，アテローム血栓症の共通した危険因子であり，障 
害される血管床が増えるほど心血管イベントのリスクは 増大する。 これらの生活習慣病は単独, あるいは複合的 にアテローム血栓症を来す危険因子と考えられ，本邦に おいても, 高血糖および高血圧の複合的危険因子は脳梗 塞などの心血管イベントのリスクであることが報告され ている13).

このように，アテローム血栓症の克服は虚血性脳卒中 の二次予防に抢いて今後重要性を増すものと考えられる が，日本人におけるこれら代謝性危険因子の管理は不十 分とされている. 日本人の脳卒中, 心筋梗塞, 心房細動 患者に対する多施設共同研究である J-TRACE (Japan Thrombosis Registry for Atrial Fibrillation, Coronary or Cerebrovascular Events)のベースラインデータにおける危 険因子の未治療率は糖尿病および高コレステロール血症 でそれぞれ 36.9, $29.8 \%$ と高率であり，これを裏付けて いる ${ }^{14)}$. 虚血性脳卒中患者に扔いて, 複合的危険因子を 治療することがどの程度二次予防に寄与するかは不明で あるが，複合的危険因子を治療することで脳卒中の発症 リスクが軽減されることが示唆されており ${ }^{15)}$, 今後, 代 謝性疾患を包括的に改善させることが虚血性脳卒中の再 発予防につながることが期待される.

また, 今回の研究結果では, 虚血性脳卒中後の死亡群 に打いて, 糖尿病の頻度が有意に高かった。わが国の糖 尿病患者の死因調查からは, ここ 30 年間を通して糖尿 病患者が非糖尿病患者に比べて 10 年短命であることが 報告され ${ }^{16)}$ ，虚血性脳卒中発症後の死亡と糖尿病との関 係が指摘されている ${ }^{17-20)}$. 本研究では, 死亡原因が特定 できない症例も含まれ，また解析対象が少ないこともあ り, 心血管イベントと関連した死亡と生活習慣病との関 係は明らかにされていない，本研究に扔ける死亡例は, 癌 $(\mathrm{n}=8)$ および肺炎などの感染症 $(\mathrm{n}=10)$ によるものが全 体の半数以上を占め, 心血管イベント $(\mathrm{n}=11)$ 以外の原因 による死亡が多いことが示唆される，糖尿病を有する虚 血性脳卒中患者において，その後の死亡が有意に高いこ とは, 糖尿病存在下のアテローム血栓症が全身の動脈硬 化を基盤として複数の血管床のイベントを合併しやすい 背景以外にも, 糖尿病が感染症などのリスクを増大させ ることも考えられる．また，糖尿病患者の大規模前向き 研究に打いて, 糖尿病は主要な危険因子とは独立し, 癌 や感染症による早期死亡と関連することが報告されてい $る^{21)}$. 本研究の結果から, mRS や糖尿病などの生活習慣 病が虚血性脳卒中発症後の死亡と関係していることは, 患者の全身状態によって抗血栓療法の継続や癌の早期発 見が困難になる, あるいはこれらの背景に加え, 生活習 慣病の存在が複合的に死亡に関与していることが考えら
れる。

本研究の問題点は, 2 年間の観察期間における虚血性 脸卒中の再発率が既報告と比較し低いことが挙げられ る. 虚血性脳卒中の再発は，対象が一般住民か否か，あ るいは対象の重症度によっても異なるが，3.81〜 14.1\% 程度と報告されている ${ }^{22-24)}$. 本研究で再発率が低い理由 としては，観察期間における電話でのインタビューでは 軽症の虚血性脳卒中再発を十分に拾い上げることができ なかった可能性が考えられる。 また, 日本人の The Reduction of Atherothrombosis for Continued Health (REACH) registry のサブ解析データでは抗血小板療法を 受けた症例は全体の $73.9 \%$ にとどまり ${ }^{25)}$, REACH registry などでみられる抗血小板療法の頻度と比べ, 抗 血小板療法が高率に行われている結果, 再発が低く抑制 された可能性も考えられる，解析対象は，虚血性脳卒中 登録症例 $(n=4,654$, 平均年齢 $73.5 \pm 11.8$, 男性 $60.1 \%$ )の $11.7 \%$ であり，登録症例と比較し解析症例の平均年齢が 若いこと，また，心原性脳塞栓症に関係した心房細動以 外の心疾患の情報が得られていないこと, 高血圧症の定 義において, 高血圧症の既往以外の臨床情報が得られな かったことも問題点として挙げられる.

今後, より多くの初発症例を対象とし, 長期観察を行 うことで, 生活習慣病の複合的リスクと虚血性脳卒中の 再発との関係が明らかにされることが望まれる.

また, 今回の研究では, 生活習慣病のコントロール状 態が再発に与える影響を明らかにすることはできない が，虚血性脳卒中に対し，スタチンの有用性をみる Japan Statin Treatment Against Recurrent Stroke 試験や，脳 卒中患者に対し厳格降圧によるイベント抑制効果を検討 する多施設共同前向き試験 Recurrent Stroke Prevention Clinical Outcome 研究などが現在進行中であり, これら の研究結果が二次予防に有用なデー夕をもたらすことが 期待される。

\section{結 語}

虚血性脳卒中再発および死亡には，糖尿病などの生活 習慣病が複合的に関係していた，今後，長期観察による 研究から, 代謝性危険因子が虚血性脳卒中の再発, およ び死亡に与える影響が明らかにされることが望まれる。

筆頭著者は日本脳卒中学会への COI 自己申告を完了 しており，本論文の発表に関して，開示すべきCOI は ない.

但し, 山形県対脳卒中治療研究会には, 大塚製薬 (株), 塩野義製薬(株), ノバルティスファーマ(株), 
ファイザー(株), 第一三共(株)より, 研究費, 奨学寄付 金(奨励寄付金)を受けているメンバーも含んでいること を申し添える。

Appendix

*山形県対脳卒中治療研究会 $(50$ 音順)

赤坂雅弘日本海総合病院脳神経外科

熱海裕之国立病院機構山形病院内科

伊藤健司＼cjkstart米沢市立病院脳神経外科

加藤丈夫 山形大学医学部内科学第三講座

鎌塚栄一郎 北村山公立病院脳神経外科

嘉山孝正 山形大学医学部脳神経外科

金城利彦公立置賜総合病院脳神経外科

朽木秀雄出形済生病院脳神経外科

(現 山形県立河北病院脳神経外科)

久保田功 山形大学医学部内科学第一講座

熊谷 孝山形県立中央病院脳神経外科

小久保安昭 山形大学医学部脳神経外科

近藤 礼 山形市立病院済生館脳神経外科

斎藤伸二郎 山形市立病院済生館脳神経外科

斎藤博文山形県立河北病院脳神経外科

(現 北村山公立病院脳神経外科)

佐藤和彦鶴岡市立荘内病院脳神経外科

鹿間幸弘山形県立河北病院神経内科

鈴木義広白本海総合病院神経内科

蘇 慶展山形県立新庄病院脳神経外科

飛田宗重国立病院機構米沢病院神経内科

成松宏人等大学医学部公衆衛生学講座

山川達志山形県立中央病院神経内科

和田 学 山形大学医学部内科学第三講座

\section{参考文献}

1) Rothwell PM, Algra A, Amarenco P: Medical treatment in acute and long-term secondary prevention after transient ischaemic attack and ischaemic stroke. Lancet 377: 1681-1692, 2011

2) Kannel WB, Wolf PA, McGee DL, et al: Systolic blood pressure, arterial rigidity, and risk of stroke. The Framingham study. JAMA 245: 1225-1229, 1981

3) Abbott RD, Donahue RP, MacMahon SW, et al: Diabetes and the risk of stroke. The Honolulu Heart Program. JAMA 257: 949-952, 1987

4) Hardie K, Hankey GJ, Jamrozik K, et al: Ten-year survival after first-ever stroke in the perth community stroke study. Stroke 34: 1842-1846, 2003

5) Hart CL, Hole DJ, Smith GD: Risk factors and 20-year stroke mortality in men and women in the Renfrew/Paisley study in Scotland. Stroke 30: 1999-2007, 1999

6) Shinohara $Y$, Gotoh F, Tohgi H, et al: Antiplatelet cilostazol is beneficial in diabetic and/or hypertensive ischemic stroke patients. Subgroup analysis of the cilostazol stroke prevention study. Cerebrovasc Dis 26: 63-70, 2008

7) Special report from the National Institute of Neurological Disorders and Stroke. Classification of cerebrovascular diseases III. Stroke 21: 637-676, 1990

8) Kubo M, Kiyohara Y, Kato I, et al: Trends in the incidence, mortality, and survival rate of cardiovascular disease in a Japanese community: the Hisayama study. Stroke 34: 2349-2354, 2003

9) Tight blood pressure control and risk of macrovascular and microvascular complications in type 2 diabetes: UKPDS 38. UK Prospective Diabetes Study Group. BMJ 317: 703-713, 1998

10) Matsumoto K, Miyake S, Yano M, et al: Insulin resistance and classic risk factors in type 2 diabetic patients with different subtypes of ischemic stroke. Diabetes Care 22: 1191-1195, 1999

11) Dormandy JA, Charbonnel B, Eckland DJ, et al: Secondary prevention of macrovascular events in patients with type 2 diabetes in the PROactive Study (PROspective pioglitAzone Clinical Trial In macroVascular Events): a randomised controlled trial. Lancet 366: 1279-1289, 2005

12) Hu G, Sarti C, Jousilahti P, et al: The impact of history of hypertension and type 2 diabetes at baseline on the incidence of stroke and stroke mortality. Stroke 36: 2538-2543, 2005

13) Kokubo Y, Okamura $T$, Watanabe $M$, et al: The combined impact of blood pressure category and glucose abnormality on the incidence of cardiovascular diseases in a Japanese urban cohort: the Suita Study. Hypertens Res 33: 1238-1243, 2010

14) Uchiyama $S$, Shibata $Y$, Hirabayashi $T$, et al: Risk factor profiles of stroke, myocardial infarction, and atrial fibrillation: a Japanese Multicenter Cooperative Registry. J Stroke Cerebrovasc Dis 19: 190-197, 2010

15) Hackam DG, Spence JD: Combining multiple approaches for the secondary prevention of vascular events after stroke: a quantitative modeling study. Stroke 38: 1881-1885, 2007

16）堀田 饒：日本人糖尿病患者の死因とその変遷. 日本臨 牀 70: 234-240, 2012

17) Winell K, Pääkkönen R, Pietilä $A$, et al: Prognosis of ischaemic stroke is improving similarly in patients with type 2 diabetes as in nondiabetic patients in Finland. Int J Stroke 6: 295-301, 2011

18) Jia $Q$, Zhao $X$, Wang $C$, et al: Diabetes and poor outcomes within 6 months after acute ischemic stroke: the China National Stroke Registry. Stroke 42: 2758-2762, 2011

19) Andersen KK, Olsen TS: One-month to 10-year survival in the Copenhagen stroke study: interactions between stroke severity and other prognostic indicators. J Stroke Cerebrovasc Dis 20: 117-123, 2011

20) Eriksson M, Carlberg B, Eliasson M: The disparity in long-term survival after a first stroke in patients with and without diabetes persists: the Northern Sweden MONICA study. Cerebrovasc Dis 34: 153-160, 2012

21) Emerging Risk Factors Collaboration, Seshasai SR, Kaptoge $S$, et al: Diabetes mellitus, fasting glucose, and risk of causespecific death. N Engl J Med 364: 829-841, 2011

22) Azarpazhooh MR, Nicol MB, Donnan GA, et al: Patterns of stroke recurrence according to subtype of first stroke event: the North East Melbourne Stroke Incidence Study (NEMESIS). Int J Stroke 3: 158-164, 2008 
23) Hier DB, Foulkes MA, Swiontoniowski M, et al: Stroke recurrence within 2 years after ischemic infarction. Stroke 22: 155-161, 1991

24) Suzuki N, Sato M, Houkin K, et al: One-year atherothrombotic vascular events rates in outpatients with recent non-cardioembolic ischemic stroke: the EVEREST (Effective Vascular Event REduction after STroke) registry. J Stroke Cerebrovasc Dis 21:
245-253, 2012

25) Uchiyama $S$, Goto $S$, Matsumoto $M$, et al: Cardiovascular event rates in patients with cerebrovascular disease and atherothrombosis at other vascular locations: results from 1-year outcomes in the Japanese REACH Registry. J Neurol Sci 287: 45-51, 2009

\title{
Abstract \\ Risk factors associated with stroke recurrence and death in patients with ischemic stroke of Yamagata prefecture in Japan
}

\author{
Yamagata Society in Treatment for Cerebral Stroke (YSTCS)
}

Background and Purpose: Although hypertension and diabetes are strong predictors for stroke, only few studies have investigated their combined impact on stroke recurrence. We investigated the relationship between clinical characteristics of the ischemic stroke patients and stroke recurrence, and their association with all-cause mortality within 2 years after onset.

Methods: A total of 544 ischemic stroke patients, living in the Yamagata prefecture, were enrolled in this study. We evaluated the clinical characteristics of patients on admission, and followed their clinical courses for 2 years.

Results: During mean follow up of 22.4 months, 25 incident ischemic stroke events were found. Furthermore, 34 patients died during follow up. On multivariate Cox hazard regression analyses, combination of hypertension, diabetes, hypercholesterolemia (HR 2.72, $\mathrm{p}=0.033$ ), and past history of stroke (HR 3.69, $\mathrm{p}=0.001$ ) were independent predictors of stroke recurrence. The results of multivariate Cox hazard regression analyses also showed that age (HR 1.05, per 1-year increase), presence of hypertension and diabetes (HR 2.99), anti-thrombotic therapy (HR 0.18), lacunar infarct (HR 0.14), cardiogenic embolism (HR 2.45), and the scores of modified Rankin scale (HR 2.75, per 1 score increase) were independent predictors of all-cause mortality.

Conclusion: The results of the present study indicate that joint effects of diabetes, hypertension, and hypercholesterolemia are at increased risk for ischemic stroke recurrence. Diabetes appeared to be associated with all-cause mortality, and joint effect of hypertension and diabetes are independent risk for all-cause mortality within 2 years after the onset of ischemic stroke.

Key words: ischemic stroke, stroke recurrence, all-cause mortality, risk factors, secondary prevention

(Jpn J Stroke 36: 425-431, 2014) 